\title{
Some thoughts on systems in management
}

\author{
K. Sandrock
}

In order to deal successfully with planning and decisionmaking, managers have come to make extensive use of scientific problem-solving disciplines. Now a well-defined problem can come to a satisfactory solution. Indeed, the difficulty lies in trying to determine exactly what the real problems are, and to stop focusing on their symptoms. In this respect, classical methods of using technology are not adequate to deal with complex situations. What is required is a change in the approach to the examination of problem areas. It is suggested that thinking should be navigated away from the deliberate narrowing down of the area of concern (reductionism), towards a richer, and broader systemic orientation. In order to structure problem situations at this meta-level, the concepts of systems engineering can be of value. This article attempts to illustrate briefly in what respects the systems approach differs from classical technique oriented approaches; and how systems thinking may be used in dealing with situations in which there are many considerations.

S. Afr. J. Bus. Mngmnt. 1979, 10: 17-21

Met die oog op geslaagde hantering van beplanning en besluitneming, maak bestuurders in die jongste tyd op groot skaal gebruik van wetenskaplike dissiplines vir probleemoplossing. Nou kan 'n goed-gedefinieerde probleem tot by 'n bevredigende oplossing kom. Daar moet bepaal word wat die werklike probleme is, en nie op simptome gekonsentreer word nie. In hierdie opsig is klassieke metodes van tegnologieaanwending nie voldoende om komplekse situasies te hanteer nie. Wat benodig word, is ' $n$ verandering in die benadering tot die ondersoek van probleemgebiede. Dit word voorgestel dat die dinkproses weggestuur moet word van die doelbewuste vernouing van die area van ondersoek (reduksionisme) in die rigting van 'n ryker, en brë̈r sistemiese oriëntasie. Ten einde probleemsituasies op hierdie meta-vlak te struktureer, kan die konsepte van die sisteembenadering van waarde wees.

Hierdie artikel poog om aan te toon in watter opsigte die sisteembenadering van klassieke tegniek- georiënteerde benaderings verskil; en hoe sisteemdenke gebrulk kan word in die hantering van situasies wat kompleks is.

S.-Atr. Tydskr. Bedrytsl. 1979, 10: 17-21

Chief Mathematical Statistician,

City Engineer's Department, Municipality of Johannesburg,

P.O. Box 4323, Johannesburg 2000

Received 27 October 1978; revised 19 January 1979
Over the past twenty-five years or so, a number of managers have introduced scientific disciplines into their organizations in order to improve their planning and decision-making processes. Examples of such disciplines are: Operations Research, Management Science, Work Study, and Organization and Method Study. At this point in time the level of modelling, analytical, and computing expertise which has been reached, is such that there is no longer any great difficulty in getting from a problem to a satisfactory solution.

Thus managers are now free to concentrate on meta-level aspects of planning, decision-making, and control. (The prefix 'meta' in the sense used here means 'beyond and above'.) This has become increasingly necessary because the introduction of scientific methods has usually not resulted in a balanced approach to problem-solving within organizations.

Instead, the focus continues to be on the treatment of symptoms (often in an ad hoc fashion), rather than on recognizing and doing something about the deep-rooted ills which give rise to these symptoms. What is required to improve upon this situation is the adoption of an approach which will enable managers to 'engineer' the subsystems which comprise the organization, so as to attain overall objectives more efficiently, and more effectively, than is possible using piecemeal methods. There exists just such an approach. It has gained wide acceptance over the past fifteen years. It is known as Systems Engineering.

In Europe, Systems Engineering was born and was subsequently developed in the oil, chemical, and power generation industries because these were three of the most complex and technologically advanced industries in existence at the time. More recently, it is being used in a much broader spectrum of enterprises - and also by governmental agencies and local authorities.

In the USA the initial development and popularization of systems engineering was due to the work of the $R$ and Corporation (established in 1947), and other government sponsored organizations. In August 1965, President Johnson ordered the adoption of the principles of programmed management and systems analysis in the majority of Federal institutions.

To keep pace with the demand for systems engineers, a 
number of universities abroad are offering post-graduate degrees (and some undergraduate courses) in the discipline. The first Department of Systems in the United Kingdom was established at the University of Lancaster in 1965 by Professor G.M. Jenkins. Associated with the department is the consulting firm of ISCOL (International Systems Corporation of Lancaster Ltd.) which has undertaken a great number of systems projects in both large and small organizations. As a result of this real-world experience it has been possible to develop outstanding course work at Lancaster. Some aspects of a Lancaster approach to systems engineering are discussed in a later section of this article.

\section{A definition of systems engineering}

Systems Engineering is the professional, intellectual, and academic discipline for the analysis and design of complex systems by the efficient use of resources in the form of men, money, machines, and materials, so that the individual subsystems making up the overall system can be fitted together in the most efficient way. Or, more broadly, it is a systemic approach to a problem situation. In this context a system can be defined as: a grouping of men, machines, and resources, which is composed of interacting subsystems.

In order to avoid confusion with other types of systems (such as computer systems for example), a man/machine system is referred to as a 'human activity system'.

The most important difference between the systems approach and the approaches generally adopted by management science disciplines is that while the latter are reductionist in nature, the former strives to be 'beyond reductionism'. That is, it places emphasis on synthesis, and not only on analysis. In so doing it seeks to investigate the wider systems of which the system being studied is part. This has important implications. For example, one may consider the familiar problem of a subsystem within an organization which has difficulty in attaining certain objectives. A reductionist approach would take the objectives as 'given' and would seek to optimize those processes which are relevant to the attainment of these objectives. On the other hand, the systems approach by virtue of its examination of wider issues, would include a study of the system in which objectives and measures of performance are decided upon. If the real problems are located in this wider system, the approach would uncover them, and would seek to engineer the 'objective setting', and 'performance measuring' processes (as well as the 'objective attainment' processes), as part of an overall optimization policy. The thinking behind these two approaches is depicted in Fig. 1 and Fig. 2.

\section{'Hard' systems engineering and 'eoft' systems engineering}

Early applications of systems engineering were almost wholly confined to the systematic optimization of man/machine systems. This is known as 'hard' systems engineering. According to this view the task to be accomplished is that of conceiving, designing, and implementing a system to meet some defined need. (Note that thinking in terms of a system is meta-level compared with thinking in terms of a model). The first step in a 'hard' analysis is to ask: What are the objectives to be attained by the system? The answer to this question determines the

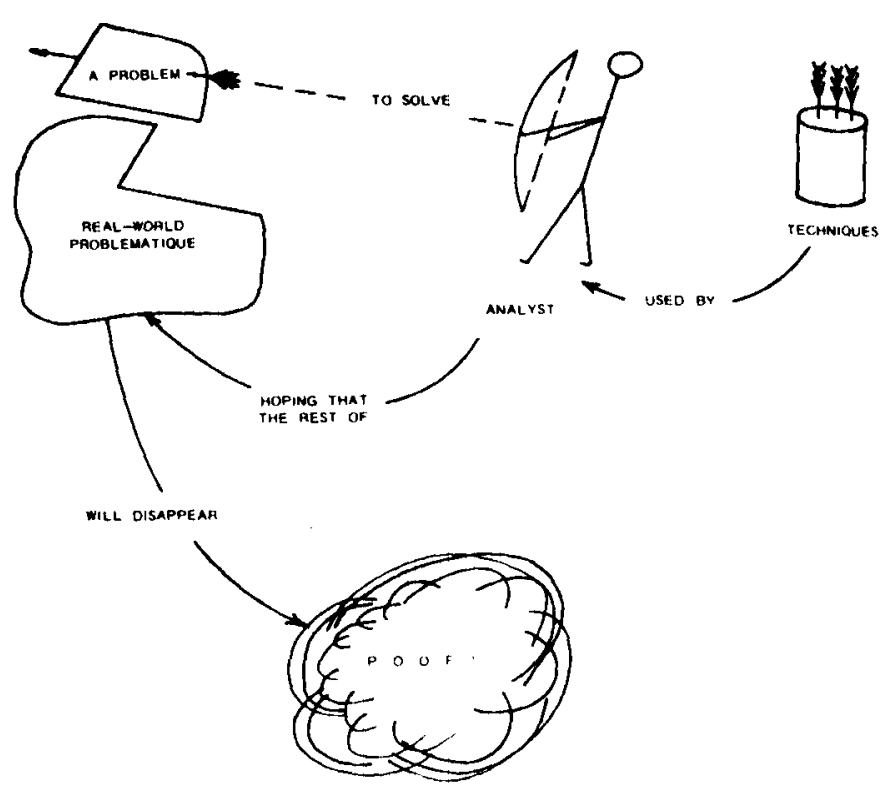

Fig. 1 The reductionist approach to problem-solving

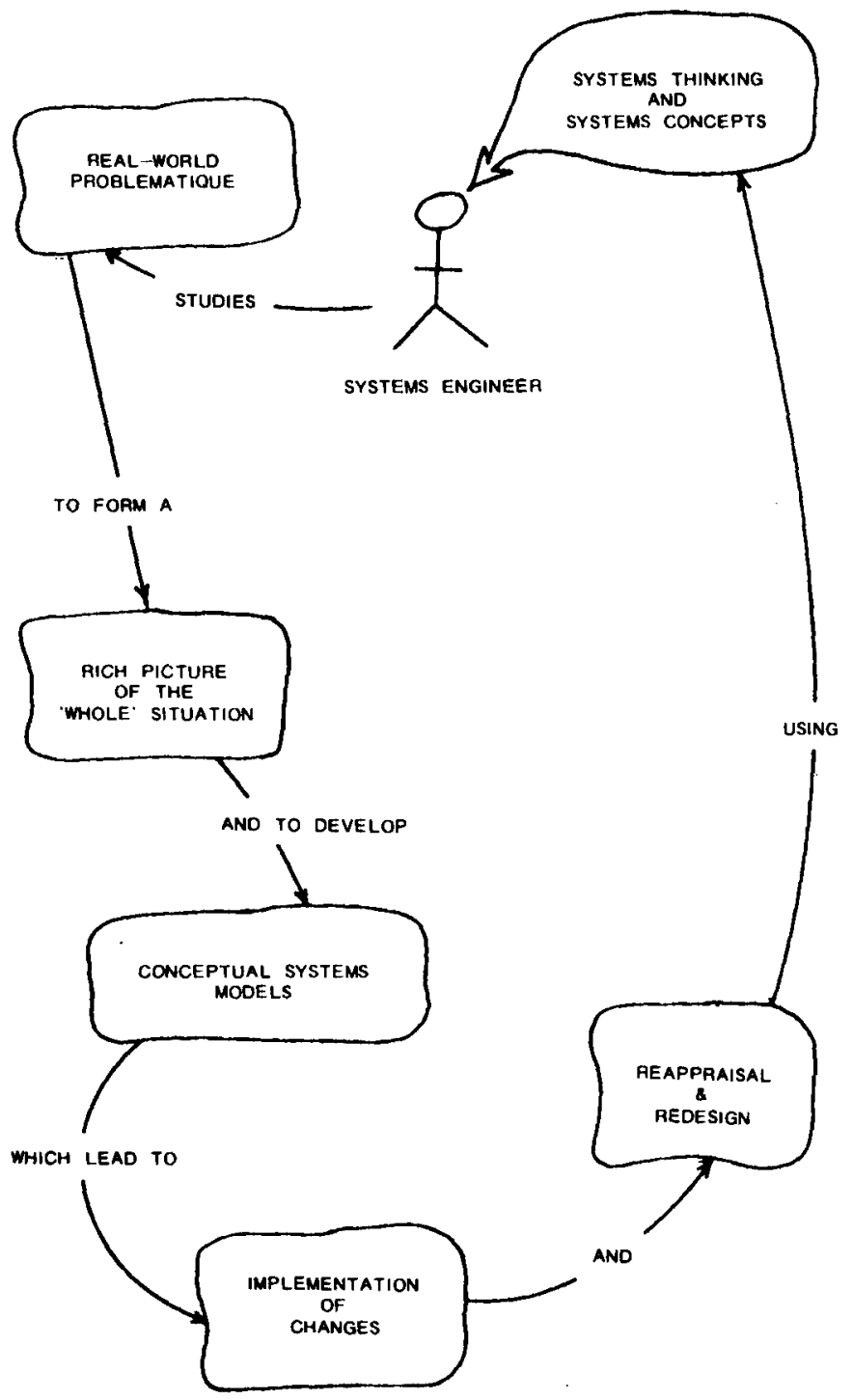

Fig. 2 A systems approach to problem-solving 
need to be satisfied in the engineering of a system so that it changes from its current state to a preferred state which is more efficient in terms of some prescribed measure of performance. The next step in the analysis is to select the best alternative for effecting this transition.

Building on the success of hard systems engineering, systems thinking began to be applied to situations in which the human element is of paramount importance. This is the area of 'soft' systems engineering which is fraught with difficulty because in a 'soft' situation it is usually not possible to answer, in a precise manner, questions about missions, objectives, needs, and measures of performance. Human systems are notorious for having a plurality of fuzzy, ill-defined, seldom quantifiable, goals and objectives. There are two ways of getting around these problems. The first is to press the analysis in hard terms - but this will rob it of its richness. The second is to construct a metamethodology and a metalanguage for studying soft systems. Most practitioners have adopted the former approach.

At Lancaster, attempts have been made to proceed in the direction of the second alternative. This has led to the development of a methodology (described in the next section), which has proved to be effective in the analysis of complex real-world situations. It is a systemic approach which should be of particular interest to managers because it adds a new dimension to the investigation, design, and optimization of organizational systems. The key word in the above sentence is the word systemic. It expresses a concern for the 'whole' and for the syntheses associated with holism.

An important fact in this regard is that the whole exhibits properties which cannot be deduced from an examination of its parts, i.e. that it is more than the sum of its parts. This concept may be illustrated quite simply as follows: Consider the sequence of natural numbers which man created in order to count things. This is a designed abstract system. If we examine a big enough chunk of it we find that it exhibits properties over and above those concerned with counting per se. For example, there is a distinction between odd numbers and even numbers and there are such things as prime numbers, etc. None of these properties of the system are deducible from an examination, in isolation, of its components. Only when we study it as a whole do we see it in its full richness. This is of course even more true of human activity systems because of their complexity, because of the plurality of processes and cybernetic loops existing within them, and because their human components generate a multiplicity of interactive on-going relationships - to mention but some of their important characteristics.

\section{A 'soft' methodology}

Any organizational 'problematique' (that is, problem system, or more picturesquely, Pandora's box of problems), is composed of both purposeful and purposive systems. The distinction is extremely important. Purposeful systems (i.e. human activity systems), are capable of wilful action and of being able to originate objectives within their boundaries. Purposive systems, on the other hand, are there to serve a purpose - their decision-takers are located somewhere in the wider systems of which they are part. Purposive systems comprise the set of designed physical systems, designed abstract systems, and natural systems.

In order to conduct a rich study of human activity systems they should not be treated as if they are purposive. To err in this way is to press the analysis in hard terms and, as mentioned earlier, to grossly over-simplify the real-world situation. A soft analysis is very careful to take purposeful considerations explicitly into account. But most technique oriented disciplines do not do so. In fact many management science analysts may be blissfully unaware of the simplifying assumptions which their methodologies automatically incorporate into their models. The main reasons for this state of affairs are: that their training has concentrated on getting from a problem to a solution, and not on the structuring of problem situations, and the techniques of their respective disciplines are quantitative, analytical tools which cannot cope with qualitative, purposeful variables.

As opposed to this type of reductionist approach, the broader systems view proposes that a problem solver should not be morphology-bound, but that if necessary, he or she should be capable of constructing a suitable methodology (and choosing an appropriate language), for studying a particular situation. Problem solvers should, therefore, not only be thinking in terms of systems instead of models, but also in terms of methodologies (:"the method of method'), instead of methods per se. The construction of a tailor-made methodology can be expedited if use is made of known approaches from which to extract and assemble appropriate elements.

In order to illustrate how soft situations may be analysed, the approach due to Professor P. Checkland', of Lancaster University, is outlined below.

Referring to Fig. 3, steps 1 and 2 result in the formation of a structured, rich picture of the problematique, and its wider, and yet-wider systems. This picture should be as weltanschauung-free (i.e. as personal-viewpoint-free) as possible. To achieve this, statements made by problem owners within the system as to 'what the problem is' are taken seriously enough, but are not permitted to cloud the analyst's thinking, or to precipitate any a-priori assumptions as to what the real needs are.

Step 3 is particularly interesting and leads to a set of concise descriptions of all the relevant systems within the boundary of the problematique. In order to formulate these descriptions (called root definitions) and to proceed to step 4, the systems engineer finds it necessary to retire into what may be called the 'systems thinking world'. This does not mean that he loses touch with reality altogether, but it does mean that his main concern is for creativity, insight, and conceptualization in systems terms, until the return to the real-world situation in step 5 .

The conceptual models developed in step 4 can take a number of forms. Usually they are parsimonious activity models in which each activity is itself a subsystem of the problematique. On the other hand they may have some mathematical content. They could also be the intersections of input/output and technology cotyledons, as described by Wymore. ${ }^{2}$ Whatever form these models may take, they should never be regarded as ideal models. Checkland ${ }^{3}$ makes this point emphatically, saying: 'It is unpardonable arrogance to purport to know what is "ideal" or what "ought" to exist. The conceptualization is seen as a means of establishing a frame-work in which the possibilities can be expressed coherently: it has a clarifying function, not a normative one.' 


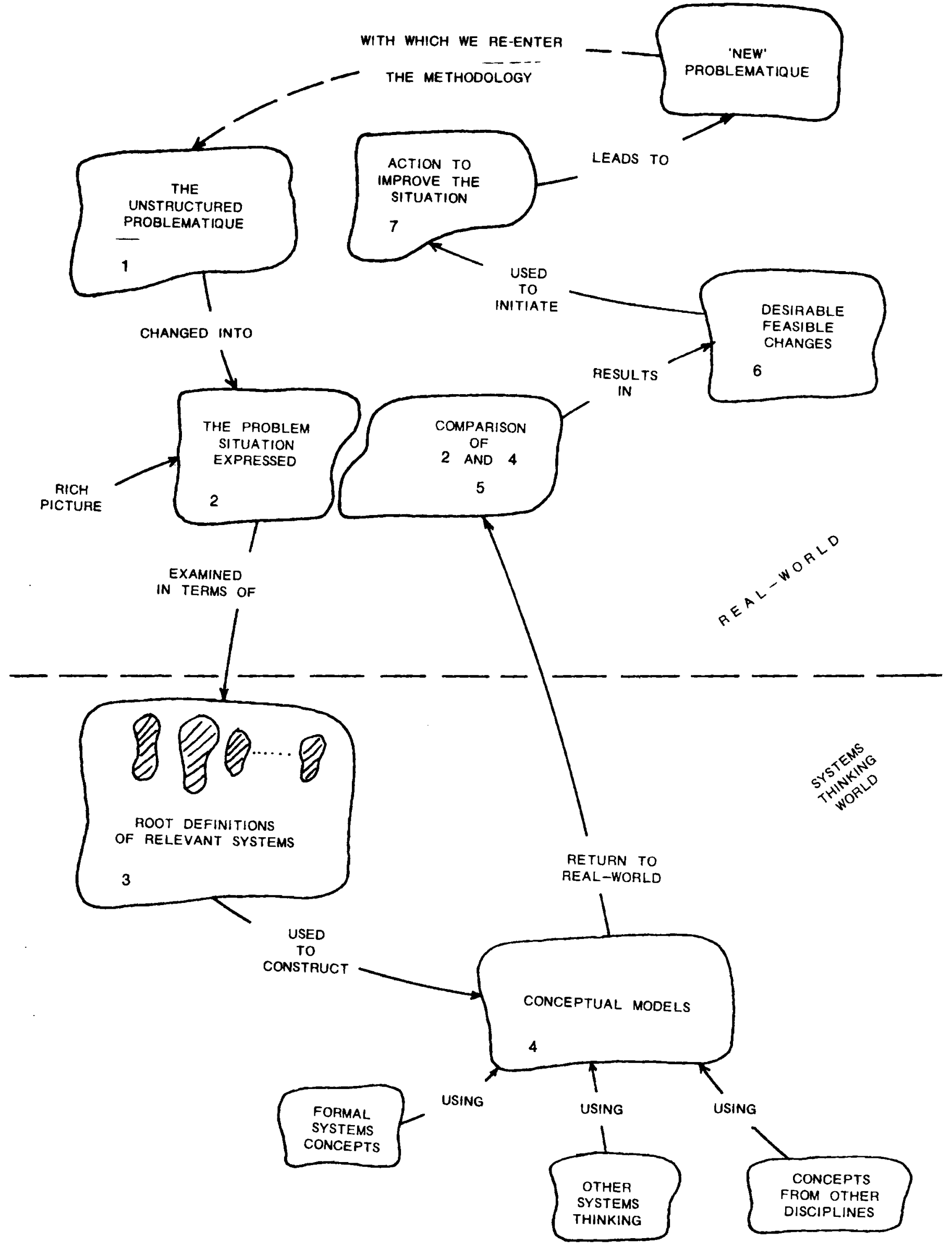


Step 5 is unique to this approach. It is a return to the realworld in order to compare the systems models alongside the problematique expressed in step 2 . Together with the actors in the problem situation, the systems engineer sets up a debate about change. Only at this point the real problems are isolated and desirable feasible changes generated. Other methodologies, such as those of the management sciences for example, do not have such a step since they accept as given what change is needed.

Finally, Checkland's approach does not terminate with the implementation of change. On the contrary, it is made explicit in the methodology (steps 6 and 7), that whatever proposals are implemented, they can only lead to the formation of a new problematique which must itself be engineered. We thus have Pandora's boxes within Pandora's boxes. What should not be lost sight of is the important fact that with the opening up of each new problem situation a yet richer picture of the organization emerges. In this respect the methodology supports Popper's reasoning (see Magee) which proposes that implementation results in the creation of a new need, or a new set of aims. This aimstructure cannot be taken as 'given' but it develops with the help of some kind of cybernetic mechanism out of earlier aims, and out of results which were not aimed at. In this way a whole new situation arises largely as a result of the autonomy of the human components of the system. The approach also recognizes the fact that human activity systems can only be changed in stages through a critical feedback process of successive adjustments.

A point which has been made by Sir Geoffrey Vickers in his writings ${ }^{3}$ is that purposeful systems are affected by the history of ideas as well as by the history of events. It is, therefore, necessary to gain an understanding of (and possibly engineer) the 'human acceptance' systems within the organization if one wishes to ensure a smooth transition from conceptualization to implementation. Checkland allows for this in steps 5 and 6.

\section{Conclusion}

Ackoff $^{6}$ points out that a problematic situation, from a systems point of view, is never indivisible, i.e. containing only one problem. He refers to systems of problematic situations as 'messes'. And he says: 'If we approach these messes analytically by breaking them down and finding independent solutions then we may create a worse mess.'

Systems engineering, in striving to be beyond reductionism, attempts to get from a mess to a problem situation which is less of a mess. What this implies, essentially, is that thinking systemically is meta-level to thinking systematically, and that it is a more useful approsch to adopt.

This article addresses itself in part to the difficulties which are peculiar to the soft end of the systems spectrum. It attempts to illustrate how these difficulties may be overcome through the use of a methodology which does not rely on a-priori assumptions as to 'what the problems are'. It is pointed out that the implementation of change in a soft system cannot be disruptive and that it must take place in increments which can be accommodated by the human component. With each transition from a current state to a preferred state a yet richer picture of the overall situation emerges.

The author has stated that a problem solver should not be methodology-bound, but that he should be capable of constructing a tailor-made approach if the situation demands it. Sage' also makes this point. He says: 'There is no unique systems engineering methodology. Problems in large-scale systems, particularly in the societal sector, dealing with economic factors, resource factors, technological factors, and very difficult to quantify behaviour factors, are most complex. Thus it is doubtless unrealistic to expect the development of a unique standard methodology.'

In contrast to this way of thinking, most management science disciplines place great emphasis on getting from a problem to a solution via a standard methodology and the use of prototype models. This approach has certainly yielded some pretty good suboptimizations over the years. But to cope with organizational complexity we really need to work at a systemic level, or even at a metasystemic level. This can be far more fruitful than relying solely on classic reductionist procedures.

\section{References}

1 CHECKLAND, P. 1976. Towards a Systems-based Methodology for Real-world Problem Solving. In: Systems Behaviour (Ed. J. Beishon \& G. Peters) Harper \& Row, London, p.51-78

2 WYMORE, A.W. 1976. Systems Engineering for Interdisciplinary Teams, John Wiley \& Sons, Inc., New York, Ch. 2 and 3

3 CHECKLAND, P. no date. Lecture Notes used in Masters Courne in Systems in Management at Lancaster University

4 MAGEE, B. 1973. Popper, Fontana Books, Ch. 5

5 VICKERS, Sir Geoffrey, 1972. Freedom in a Rocking Boat, Petican Books, Middlesex, England, p. 197-203

6 ACKOFF, R.L. 1973. Planning in the Systems Age.Santhya Seried B, p.149 et seq.

7 SAGE, A.P. 1978. Methodologies for Socio-economic Resource Systems Modelling. J. Interdisciplinary Modelling and Simulation 1: $1-95$ 